\title{
Eve Geçiş: Preterm Ebeveyn Ölçeği'nin Türkçe Geçerlik ve Güvenirlik Çalışması
}

\section{Transition to Home: Turkish Validity and Reliability Study of the Preterm Parental Scale}

\author{
${ }^{1}$ Hamide ZENGIN, ${ }^{2}$ Öznur TİRYAKİ, ${ }^{3}$ Nursan ÇINAR
}

${ }^{1}$ Bilecik Seyh Edebali Üniversitesi, Sağlık Bilimleri Fakültesi, Çocuk Sağlı̆̆ı ve Hastalıkları Hemşireliği Anabilim Dalı, Bilecik, Türkiye ${ }^{2}$ Sakarya Üniversitesi, Sağlık Bilimleri Enstitüsü, Hemşirelik Doktora Programı, Sakarya, Türkiye

${ }^{3}$ Sakarya Üniversitesi, Sağlık Bilimleri Fakültesi, Çocuk Sağlığı ve Hastalıkları Hemşireliği Anabilim Dalı, Sakarya, Türkiye

Hamide Zengin: https://orcid.org/0000-0002-2389-6466

Öznur Tiryaki: https://orcid.org/0000-0001-8788-3077

Nursan Çınar: https://orcid.org/0000-0003-3151-9975

\section{ÖZ}

Amaç: Bu çalışma "Eve Geçiş: Preterm Ebeveyn Ölçeğii" nin (EG:PEÖ) Türkçe kültürel adaptasyonunun yapılması ve geçerlik, güvenirliğinin test edilmesi amacıyla yapılmiştır.

Materyal ve Metot: Araştırmanın Türkçe geçerlik ve güvenirliliğinin yapılması için ölçek sahibinden elektronik posta yolu ile izin alındıktan sonra etik onay, hastane yönetiminden yazılı ve ebeveynlerden sözel izin alınmıştır. Araștırmanın örneklemine bir eğitim ve araştırma hastanesinin Yenidoğan Yoğun Bakım Ünitesi'sinde (YYBÜ) tedavi görüp taburcu edildikten sonra bir gün ile 12 ay içerisinde evde olan, toplam 144 ebeveyn çalıșmaya dahil edilmiştir. Geçerlik kapsamında; kapsam geçerliği, açıklayıc1 ve doğrulayıcı faktör analizleri, ölçek güvenirliği için; iç tutarlılık güvenirliği Cronbach Alfa katsayısı,madde ayırtedicilik analizi ve 36 kişiden oluşan bir örneklem kullanılarak test-tekrar test için Sınıf İçi Korelasyon Katsayısı (ICC) hesaplanmıştır.

Bulgular: Ölçek maddeleri İngilizce'den Türkçe'ye çevrilerek dil ve kapsam geçerliği için uzman görüşüne sunulmuştur. Açıklayıcı Faktör Analizi sonucunda Kaiser Meyer Olkin değeri 0,826; Doğrulayıcı Faktör Analizi sonucunda elde edilen uyum indeksleri $\left(\chi^{2} / \mathrm{sd}\right.$ : 1,405; RMSEA: 0,053; GFI: 0,889; CFI: 0,950) olarak elde edilmiştir. Uygulanan güvenirlik analizi sonucunda; tüm ölçek ve alt boyutların Cronbach Alfa katsayısı $(\alpha)$ 0,795-0,850 arasında bulunmuştur.

Sonuç: YYBÜ'sinden taburcu olduktan sonra eve geçişteki süreçte ebeveynlerin preterm bebeğinin bakımında yaşadığ 1 güçlüklerin belirlenmesinde kolaylıkla kullanabilecek geçerli ve güvenilir bir ölçme aracı olduğu saptanmıştır.

Anahtar Kelimeler: Ebeveyn, eve geçiş, geçerlilik ve güvenilirlik, ölçek, preterm bebek

\section{ABSTRACT}

Objective: This study was conducted with the aim of working on the Turkish cultural adaptation of the "Transition to Home: Preterm Parental Scale" (TH: PES) and testing its validity and reliability.

Materials and Methods: Ethical approval, written permission from the hospital administration and verbal permission from the parents were obtained after obtaining permission from owner of the scale via e-mail for the validity and reliability of the study in Turkish. The sample of the study included a total of 144 parents who were at home within one day to 12 months after being treated in the Neonatal Intensive Care Unit (NICU). Within the scope of validity;the Intra-class Correlation Coefficient (ICC) was calculated for test-retest using internal consistency reliability, Cronbach Alpha coefficient, item discrimination analysis and a sample of 36 people for content validity, exploratory and confirmatory factor analysis, and scale reliability.

Results: Scale items were translated from English to Turkish and submitted to expert opinion for language and content validity.In consequence of the Explanatory Factor Analysis,the Kaiser Meyer Olkin value was obtained as 0.826 ; fit indices obtained as a result of Confirmatory Factor Analysis were obtained as $\left(\chi^{2} / \mathrm{sd}: 1.405\right.$; RMSEA: 0.053; GFI: 0.889; CFI: 0.950). As a result of the applied reliability analysis, the Cronbach Alpha coefficient $(\alpha)$ of all scale and sub-dimensions was found between 0.795 0.850. After the test-retest, the ICC coefficient was determined as 0.712 for the whole scale.

Conclusion: It has been determined that it is a valid and reliable measurement tool that can be easily used in determining the difficulties experienced by parents in the course of caring their preterm baby during the transition to home after being discharged from the NICU.

Keywords: Scale, parent, premature infant, transition to home, validity and reliability

Yayın Bilgisi / Article Info:

Gönderi Tarihi/ Received: 16/10/2020

Kabul Tarihi/ Accepted: 15/12/2020

Online Yayın Tarihi/ Published: 05/03/2021

Sakarya Üniversitesi Sağlık Bilimleri Enstitüsü Hemșirelik ABD,

Sakarya, Türkiye

Tel: 02644445400

E-mail: oznuritiryaki@gmail.com

Atıf / Cited: Zengin H, ve ark. Eve Geçiş: Preterm Ebeveyn Ölçeği'nin Türkçe Geçerlik ve Güvenirlik Çalıșması. Online Türk Sağllk Bilimleri Dergisi 2021;6(1):31-43. doi: 10.26453/otjhs.811439 


\section{GİRIŞ}

Bebeğin herhangi bir nedenle yenidoğan yoğun bakım ünitesine (YYBÜ) yatırılması ebeveynler için genellikle beklenmeyen bir durumdur ve yoğun stres kaynağıdır. ${ }^{1}$ Yoğun bakım ortamında birçok stres faktörü vardır. Ebeveynlerin sürece katılımı kolaylaştırmanın yanı sıra ebeveynlere taburcu olmaya hazır hissettirmek sağlık çalışanları için önemli bir sorumluluktur. ${ }^{2,3}$ Taburculuğu gerçekleşmiş prematüre bebeklerin hastane dışında da yeterli bakım alabilmesi, sağlığını sürdürebilmesi için ailenin bebeğine bağımsız bakabiliyor, olumsuz ya da olağan dış1 durumları ayırt edebiliyor olması gerekmektedir. Ebeveynlerin bebeğin evdeki bakım gereksinimlerini karşılayabilmesi için gerekli bilgi ve becerilerin taburculuk öncesi kazandırılması ve taburculuk planlamasının bundan sonra yapılması gerekir. ${ }^{3-5}$ Prematüre bebeğe sahip ebeveynlerin taburculuk sonrası bebeklerini eve götürme ve tüm sorumluluğu alma zamanı geldiğinde kendilerini güçsüz, yetersiz, endişeli, şaşkın, hazırlıksız hissettikleri bilinmektedir. ${ }^{6,7}$ Taburculuktan hemen sonraki dönem, eve geçiş dönemi olarak tanımlanır. Eve geçiş dönemi ebeveynler için kritik bir zamandır. Güvenli ortam olarak kabul ettikleri hastane ortamından ayrılmaları, bebeğin tüm sorumluluklarını ve bakımlarını üstlenmeleri gerekecektir. Eve geçiş sürecine yönelik ebeveynler yeterince bilgilendirilmeden taburcu edilirse, bebekle ilgili istenmeyen olaylar (ev kazası, beslenme güçlügü, tekrar hastane yatış vb.) hatta ölüm bile olabilir. ${ }^{2,7,8}$ YYBÜ'sinden taburcu olduktan sonra ebeveynlerin prematüre bebeklerine bakma deneyimleri, taburculuğu izleyen ilk günlerde anksiyete ile karakterize olan bir durumdur. ${ }^{9}$ Annelerin üçte birinde maternal ruh sağlığında bozulma olduğu bildirmiştir. Çoğu zaman bebekleriyle birlikte eve geçişe hazır olmadıklarını hissedebilirler. Bu durum ebeveynlerin taburculuğa yeterince hazırlanamad1ğının, dolayısı ile eve geçiş eğitimine/hazırlığına gereksinimi olduğunun göstergesidir. ${ }^{4}$ Bebeği YYBÜ'sinde yatan babaların deneyimlerini inceleyen odak grup görüşme tekniğinin kullanıldığı nitel bir çalışmada babaların bebek bakımında kendilerine güvenmedikleri, bebeklerini incitmekten ve zarar vermekten korktukları bildirilmiştir. ${ }^{10} \mathrm{Bu}$ çalışma; YYBÜ'nde bebeği yatmış olup taburcu olan bebeklerin ebeveynlerinin eve geçiş sürecinde yaşadıklarını değerlendirmek amacıyla Boykova ${ }^{8}$ tarafından geliştirilen 'Transition From Hospital to Home in Parents of Preterm Infants: Revision, Modification, and Psychometric Testing of the Questionnaire (Eve
Geçiş: Preterm Ebeveyn Ölçeği'nin Türkçe’ye uyarlanması yapılarak geçerlik ve güvenirliğine ilişkin kanıtların incelenmesi amacıyla gerçekleştirilmiştir.

\section{MATERYAL VE METOT}

Araştırmanın Etik Boyutu: Araştırmanın Türkçe geçerlik ve güvenirliliğinin yapılması için ölçek sahibinden elektronik posta yolu ile izin alındıktan sonra etik onayı için; Sakarya Üniversitesi Tıp Fakültesi Girişimsel Olmayan Etik Kurul onayı alınmış (Tarih: 03/07/2019, karar no: 39) ve hastane yöneticisinden yazılı izin alındı. Helsinki İnsan Hakları Bildirisi ile ilgili kılavuz ilkelerine uygun olarak ve bebeklerin ebeveynleri tarafindan bilgilendirilmiş onam formu alınarak araştırma yürütüldü.

Araştırmanın Tipi: Araştırma metodolojik tiptedir. Araştırmanın Yapıldı̆̆ Zaman ve Yer: Araştırma bir eğitim araştırma hastanesinde birinci, ikinci ve üçüncü düzey YYBÜ'sinden taburcu edildikten sonra eve geçiş sürecindeki 1 gün ile 12 ay içinde olan, Eylül 2019-Mayıs 2020 tarihleri arasında yenidoğan/çocuk hastalıkları polikliniğine başvuran prematüre bebeklerin ebeveynleri ile gerçekleştirildi. Araştırmanın yürütüldüğü hastanenin YYBÜ'si III. düzey 18 yatak, II. düzey 9 yatak, I. düzey 6 yatak olup toplam 33 yatak kapasitesine sahiptir. Düzey III'de doğum ağırlığı <1500 gram olan bebekler, düzey II'de doğum ağırlığı 1500-2500 gram arasında olan bebekler, düzey I'de 2500 gramdan büyük bebekler kabul edilmektedir. Ebeveynler YYBÜ'sini günde bir kez 15.00-16.00 saatleri arasında ziyaret edebilmektedirler. Bebeklerin yaşam bulguları stabil olduğunda, beslenme ve bakım uygulamalarının anneleri tarafindan verilebilmesi için anneler hastanenin anne otelinde konaklamaktadırlar.

Araştırmanın Evreni/Örneklemi: Araştırmanın evrenini son 12 ay içerisinde YYBÜ'sinden taburcu olan tüm prematüre bebeklerin ebeveynleri (N:210) oluşturdu. Dahil edilme kriterlerine (çoğul gebelik ve anomalisi olmayan, cerrahi girişim geçirmeyen) uyan, araştırmaya katılmaya gönüllü ebeveynler örneklem (n:144) grubunu oluşturdu. Araştırmanın örneklem büyüklüğü, ölçek madde sayısının 5-10 katının alınması ilkesi doğrultusunda belirlendi. Örneklemin \%25-50'si kadar bir oranla ölçeğin test tekrar testi uygulandı. ${ }^{11}$

\section{Veri Toplama Araçları:}

Ebeveyn ve Bebek Tanıtıcı Bilgi Formu: Soru formu üç bölümden oluşmaktadır. İlk bölüm ebeveynin yaşı, eğitim durumu, aile tipi, gelir düzeyi, yaşayan çocuk sayısı, çalışma durumu gibi soruları içerdi. 
İkinci bölüm; annenin doğum şekli, gebelik sayısı, doğum esnasında/sonu problem yaşama durumu, son bölümde ise YYBÜ'sinde yatan bebeğin doğum ağırlığı, doğum haftası, taburculuktaki ağırlığı, yatt1ğ1 gün sayısı, taburculuk sonrası evde geçirdiğini gün sayısı, beslenme şekli gibi sorulardan oluştu.

Eve Geçiş: Preterm Ebeveyn Ölçeği (EG: PEÖ): Özellikle hemşirelik alanında kullanılan bu ölçek, bebeklerin YYBÜ'sinden taburcu olduktan sonra, ebeveynlerin eve geçişteki sorunlarının belirlenmesi için tasarlanmıştır. Boykova ve Kenner "Geçiş Ölçeği” için iyileştirme ve doğrulama çalışmalarının yapılması önerilmiş ve 37 maddelik Geçiş Ölçeği'ni geliştirmişlerdir. ${ }^{12}$ Boykova tarafından ölçek tekrar psikometrik analizlerle desteklenerek değiştirilmiştir. $^{8}$

EG: PEÖ'i beşli likert tipinde ( $5=$ Kesinlikle Katıl1yorum, 4=Katiliyorum, $3=$ Kararsizim, 2=Katılmiyorum, 1=Kesinlikle Katılmiyorum, $0=$ Deneyimlemedim), 17 maddeden oluşmaktadır. Ölçeğin dört alt boyutu (profesyonel destek, güven, endişe, izolasyon) bulunmaktadır. Ölçeğin sekiz maddesi ters kodlanmaktadir $(3,4,6,9,11,13,15$ ve 17. maddeler). Ölçekten toplam 85 puan elde edilmektedir. Puanın artması ebeveynlerin eve geçiş sürecinde problem yaşamadıkları anlamında yorumlanmaktadır. ${ }^{8}$

Araştırma Soruları: Eve Geçiş: Preterm Ebeveyn Ölçeği, Türkçe konuşan bir toplumda geçerli ve güvenilir bir ölçek midir?

Verilerin Toplanması: Araştırma verileri bir eğitim araştırma hastanesinin YYBÜ'sinden taburcu olan prematüre bebeklerin ebeveynleriyle taburculuktan sonraki ilk 12 ay içerisinde yenidoğan yada çocuk hastalıkları polikliniğine kontrollere geldiklerinde anketler dolduruldu. Çalışmaya dahil edilme kriterlerine uygun olan, herhangi bir iletişim sorunu olmayan en az okur-yazar ya da ilkokul mezunu, bebeği en az iki gün YYBÜ'sinde yatan ebeveynlerden sadece biri çalışmaya alındı. Araştırmacılar tarafından formlar elden verilerek ebeveynlerin doldurmaları istendi. Ebeveynlerin soru formu ve ölçeği doldurma süreleri yaklaşık 10-15 dakika sürdü.

Test-tekrar test için; araştırmacılar tarafından Google Forms aracıllğıyla oluşturulan on-line anket, basit rastgele seçilen, daha önce elektronik posta adresini veren 83 ebeveyne gönderildi. Otuz altı (\% 25) ebeveyn test tekrar teste katıldı. Yanitlar Google Form üzerinden e-tables'da topland1.

Verilerin Değerlendirmesi: Araştırmada 144 katılımciya ait veriler IBM SPSS Statistics 25 paket programına aktarılarak değerlendirildi. Kategorik değişkenler için tanımlayıcı istatistikler (n, \%) verildi. Uzmanların verdiği puanların değerlendirilmesinde Kapsam Geçerlik İndeksi ve Kapsam Geçerlik Oranı hesaplandı. Ölçeğin geçerlik ve güvenirlilik analizlerinde öncelikle Açıklayıcı Faktör Analizi (AFA) çalışmalarına yer verildi; daha sonra Doğrulayıcı Faktör Analizi (DFA) çalışmaları ve son olarak faktörlerin iç tutarlılıklarını belirlemek amacıyla güvenilirlik analizi (Cronbach Alfa) ve test-tekrar test yapıldı. Çalışmanın AFA ve güvenilirlik analizi çalışmaları SPSS 25.0 paket programı aracılığı ile hesaplanırken; DFA AMOS 22.0 yazılımı ile gerçekleştirildi. Tüm istatistiksel analizlerde anlamlllık düzeyi $(p) 0,05$ olarak kabul edildi. Test tekrar testi Sınıf İçi Korelasyon (ICC) katsayısı ile sonuçland1rildı.

Ölçek Dil Geçerliliği: Dil geçerliliği için, öncelikle ölçeği geliştiren yazardan iletişim kurularak elektronik posta yoluyla izin alınmıştır. Bununla birlikte ölçek maddelerinin Türkçeye çevirisi yapılırken, dildeki en uygun cümle yapısının, deyimlerin kullanılmasına dikkat edilmesi göz önünde bulundurularak; ilk aşamada ölçek, Türkçe ve İngilizceyi iyi bilen Çocuk Sağlı̆̆ı ve Hastalıkları Hemşireliği Anabilim Dalı alanında uzman iki öğretim üyesi ve İngilizce'yi profesyonel düzeyde bilen çevirmen tarafından İngilizce'den Türkçe'ye ayrı ayrı çevrilmiştir. Daha sonra araştırmacılar tarafindan bu çeviriler değerlendirilerek, ölçeğin Türkçe formu yeniden düzenlenmiştir. Bu form bağımsız bir dil bilimci uzman tarafindan tekrar İngilizce'ye çevrilmiştir. Elde edilen ölçek, orjinalini hazırlayan kişiye gönderilerek yorum ve önerileri alınmıştır. Yapılan düzeltmeler sonrasında ölçeğin Türkçe'ye uyarlanması ve İngilizce orjinali ile arasında eşdeğerliliğinin sağlanması ile çeviri aşaması son bulmuştur.

Ölçeğin Kapsam Geçerliği: İngilizce'den Türkçe'ye çevrilen ölçek; kapsam geçerliği için uzman görüşlerine sunulmuştur. Çocuk Sağlığı ve Hastalıkları Hemşireliği Anabilim Dalı, Kadın Sağlığı ve Hastalıkları Hemşireliği Anabilim Dalı, Aile Hekimliği Anabilim Dalından olmak üzere toplam 7 uzmana gönderildi. Uzmanlardan her bir maddenin uygunluğu ve anlaşılabilirliği açısından değerlendirmesi istendi. Her bir ifadeyi 1-4 puan (1 puan: uygun değil, 2 puan: biraz uygun, 3 puan: uygun, 4 puan: tamamen uygun) arasında puanlamaları ve her madde için görüş ve önerilerini açıkça yazmaları istendi. Uzmanlardan gelen görüşler doğrultusunda maddeler tekrar gözden geçirilerek gerekli değişiklikler yapıldı.

Kapsam geçerliliği: Uzman görüşleri değerlendiri- 
lirken kapsam geçerlik indeksi kullanıldı. Davis tekniğinde ölçekte bulunan her bir madde" 1 puan: uygun değil, 2 puan: biraz uygun, 3 puan: uygun, 4 puan: tamamen uygun" olacak şekilde dörtlü yapıda değerlendirme yapılmaktadır. Her madde değerlendirirken "a) Uygun" veya "b) Madde hafifçe gözden geçirilmeli” seçeneğini seçerek işaretleyen uzmanların sayısı toplam uzman sayısına bölünerek her maddeye ilişkin Kapsam Geçerlik İndeksi elde edilmektedir. Her bir maddeyi değerlendirirken;

$K G O=\left[\frac{\begin{array}{l}\text { uygun cevabi } \\ \text { veren uzman }\end{array}}{\frac{\text { saysis }}{\text { toplam uzman }}}-1\right]$

formulü ile $\mathrm{KGO}$ oranları hesaplandı. Uzman sayısı 7 olduğundan Kapsam Geçerlik Oranı (KGO) 1 olarak belirlendi. ${ }^{16}$

Yedi uzman 17 maddenin tamamı için madde uygun ve madde hafifçe gözden geçirilme cevaplarını vermiştir. Uzman sayısı 7 olduğundan dolayı 1'e eşit olan KGO oranına sahip maddelerin \%5 anlamlılık düzeyinde kapsam geçerliğinin sağlandığı söylenebilir. Çalışmamızda Kapsam geçerlilik indeksi (KGI), KGO oranlarının ortalaması da 1 bulunmuştur. KGİ $\geq K G O ̈$ sonucuna ulaşıldığından ölçeğin kapsam geçerliği istatistiksel olarak anlamlı bulundu.

Çalışmanın Kısıtlılıkları: Babaların gündüz mesai saatlerinde çalışıyor olmasından dolayı araştırmaya katılan baba sayısının az olması çalışmamızın kısıtlılığıdır.

\section{BULGULAR}

Katılımcılara Ait Tanıtıcı Özellikler: Araştırmaya n: $129(\% 89,6)$ anne, n: $15(\% 10,4)$ baba katıld1. Kat1lımcıların $(\mathrm{n}=144)$ yaş ortalaması $31,01 \pm 5,76, \%$ 32,6'sının lise mezunu, \%66,7'sinin çalışmadığı, \% 82,6'sının sosyal güvencesinin olduğu, \%89,6'sının çekirdek ailede yaşadığ 1 ve \%70,8'inin ekonomik durumunun gelirin gidere eşit olduğu saptandı. Katılımcıların \%47,2'sinin ilk bebeği olduğu, \% 13,2'sinin daha önce prematüre bir bebeğe sahip olduğu, \%93,1'inin gebeliğin spontan olarak oluştuğu, \%75'inin acil sezeryan doğum yaptığı, \% 50,7 'sin bebeğinin cinsiyetinin erkek olduğu ve \% 51,4'ü bebeklerini sadece anne sütü ile beslediklerini belirtti. Araştırmaya katılan ebeveynlerin bebeklerinin gestasyon haftas1 ortalamas $30,74 \pm 3,13$, doğum

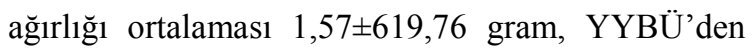
taburcu olurken ki ağırlığı 2,26 $\pm 558,13$ gram, YYBÜ'de kalış süre ortalaması 46,15 $\pm 33,55$ gün, taburculuk sonrası evde kalma süre ortalaması ise $33,55 \pm 117,34$ gün olarak bulundu. Ebeveynlerin \%54,2'sinin bebeği ile YYBÜ'de taburcu olmadan önce kanguru bakımı uyguladığı, \%82,6'sının taburcu olduktan sonra bebeğinin tekrar hastaneye yatış1nın olmadığı, \%60'4'ünün taburculuk eğitimi aldığ1, \%58,3'ünün taburcu olduktan sonra bebeğin bakımında zorlanmadığ mında eşinden destek aldı ğı, \%63,9'unun eşi dışında sosyal bir destek almadı $\breve{g}_{1}$ belirlendi.

Yapı Geçerliği: Ölçeğin yap1 geçerliğinin belirlenmesi amacıyla Açıklayıcı Faktör Analizi (AFA) ve Doğrulayıcı Faktör Analizi (DFA) yapıldı.

Açıklayıcı Faktör Analizi ve Ölçek Güvenirlik Çalışmaları: Ölçek geçerlik ve güvenirliği amacıyla yapılan bu çalışmada veriler IBM SPSS Statistic 25 paket programına aktarıldı. Öncelikle, açıklayıcı faktör analizi uygulandı ve faktör çıkarma yöntemi olarak "Temel Bileşenler Yöntemi" tercih edildi. Faktör yapısnın incelenebilmesi için örneklem yeterliliğinin belirlenmesi amacıyla Kaiser-Meyer Olkin (KMO) testi ve ölçeğe faktör analizi yapılıp yapılamayacağını belirlemek için ise Barlett's Testi uyguland1. ${ }^{11}$

Tablo 1 incelendiğinde; 17 maddeden oluşan yapıya uygulanan AFA sonucunda KMO değeri 0,826 olarak bulundu.

Ölçeğin faktör desenini ortaya koymak amaciyla AFA yapılmıştır. Tüm maddeler kavramsal olarak 4 boyuta yüklenmesi gerekirken 3 alt boyuta yüklenmiştir. "Profesyonel destek" alt boyutu Faktör 1'i, "Endişe ve İzolasyon" alt boyutu tek alt boyut olarak yüklenmiş olup Faktör 2'yi, "Güven" alt boyutu Faktör 3'ü temsil etmektedir. "Endişe ve izolasyon" alt boyutu toplam varyansin \%21,59'unun, "Profesyonel destek" alt boyutu \%19,05'ini ve "Güven" alt boyutu ise toplam varyansın \% 16,22 'sini açıklamaktadır. Bu üç alt boyut birlikte toplam varyansın \%56,87'sini açıklamaktadır ( 2).

Alfa katsayısı, ölçek maddelerinin, homojenliğinin bir ölçüsüdür. Ölçeğin alfa katsayısı ne kadar yüksek ise "ölçek maddelerin birbiriyle tutarlı ve aynı özelliğin öğelerini yoklayan maddelerden oluştuğu ya da tüm maddelerin birlikte çalıştığı” şeklinde açıklama yapılabilir. Sonuç olarak alfa katsayısı yüksekse yanıtlayıcıların ölçek maddelerine verdikleri yanıtlar birbirleri ile o derece tutarlı olmakta ve ölçek ile ilgili kavramsal yapidan ayrılmayan maddelerden oluşmaktadır. ${ }^{11}$ Uygulanan Cronbach Alfa analizi sonucunda 17 maddeden oluşan ölçeğin, 8 maddeden oluşan "Endişe ve izolasyon" alt boyutu, 4 maddeden oluşan "Güven" alt boyutu ve 5 maddeden oluşan "Profesyonel Destek" alt boyutlarının güve- 
nirlik seviyelerinin yüksek olduğu görüldü $(\alpha>0,700)$ (Tablo 2).

Doğrulayıcı Faktör Analizi Sonuçları: On yedi madde, üç faktörden oluşan yapıyı doğrulamak için kurulan ölçüm modeli analiz edildi. Analiz sonucunda modelin yeterli uyum göstermediği görüldüğünden model iyileştirme çalışmaları yapıldı. Öncelikle modifikasyon indeksleri tablosuna bakılarak modelde yapılacak olası değişiklikler için ki kare düşüş değerleri ("M.I." değerleri) incelendi. En yüksek "M.I." değerinin göstermiş olduğu modifikasyon, kavramsal olarak uygun olduğu durumlarda bağlanarak model yürütüldü. Modelin 17 madde, 3 alt boyut ile doğrulandığı görüldü.

Ölçüm modeline göre, 17 madde ile doğrulanan ölçüm modelinin hangi maddelerden oluştuğu ve tek yönlü oklar üzerindeki yollara ait standardize regresyon katsayıları yani başka bir ifadeyle faktör yükleri görülmekte olup 0,35 'in altında faktör yükü olmad1ğ1 belirlenmiştir. Ölçeğin alt boyutlarında hangi maddelerin yer aldiğ 1 ve her bir maddenin faktör yükü bulunmakta olup; ölçek maddelerinin 0,350,91 faktör yükü arasında olduğu saptandı (Șekil 1).

Tablo 3'de ölçeğin DFA uyum indeks sonuçları yer almaktadir.

Test-Tekrar Test Güvenirliği: Ölçeğin kararlılığını ölçmek için çalışmaya katılan 144 kişiden 36'sına iki hafta sonra ölçek tekrar uygulandı. Uygulanan tekrar test ile ilk test arasında yüksek uyum olduğu görüldü (ICC=0,712). Tekrar test ile ilk test arasındaki korelasyon katsayıları; "Endişe ve İzolasyon" alt boyutunda: 0,585; "Profesyonel Destek" alt boyutunda r: 0,719; "Güven" alt boyutunda r: 0,635 bulunmuştur (Tablo 4).

\section{TARTIŞMA VE SONUÇ}

Eve Geçiş: Preterm Ebeveyn Ölçeği, temelde Kenner'in geçiş modeline dayanmaktadır. Kenner'ın Geçiş Modeli'ne göre; ebeveynler bebeklerinin hastanede yattığı süre içerisinde, YYBÜ'sindeki destekleyici mekanizmalara (sağllk profesyonellerinin varlığı, YYBÜ'deki ekipman ve cihazlar) dayanarak bebeklerinin bakımına katılmaya, davranışlarını anlamaya ve bunlarla baş etmeye çalışırlar. Ebeveynler bebeklerinin tüm bakımını almaları gerektiğini fark ettikleri zaman ebeveynlik becerilerinde özgüven eksikliği yaşayabilirler. ${ }^{12}$ Boykova ve Kenner 37 maddelik "Geçiş Ölçeği'ni geliştirmişlerdir. ${ }^{13}$ Uluslararası alan yazın incelendiğinde, Eve Geçiş: Preterm Ebeveyn Ölçeği geçerlik ve güvenirlik çalışmasının Japonya'da yapıldığı belirlenmiştir. ${ }^{14}$

Ölçeğin geçerliğini sınamak için kapsam geçerliği ve yapı geçerliği yapılmaktadır. Yabancı bir dilde geliştirilmiş, geçerlilik ve güvenilirliği sınanmış, ispatlanmış olan bir ölçeğin başka bir dilde ve kültürde güvenilirlik ve geçerlik çalışmasının yapılarak kullanıma hazır hale getirilmesi dil geçerliliği olarak tanımlanmaktadır. ${ }^{15}$ Kapsam geçerliği ölçek maddelerinin, ölçülmek isteneni yeterli düzeyde karşılayıp karşılamadığını göstermektedir. Uzman görüşü almak kapsam geçerliğini değerlendirmede kullanılan bir yöntemdir. "Eve Geçiş: Preterm Ebeveyn Ölçeği” taslağı maddelerinin uygunluğunun değerlendirilmesi için uzman görüşüne sunularak kapsam geçerliği test edildi. Uzmanlardan gelen değerlendirmeler doğrultusunda her bir ölçek maddesine ait KGO hesaplandı. Uzman sayısı 7 olduğundan dolayı 1'e eşit ya da büyük olan KGO oranına sahip maddelerin kapsam geçerliğinin sağlandığı söylenebilir. ${ }^{16}$ KGİ'si KGO oranlarının ortalamasında 1,00 bulundu. KGİKGÖ değeri 1 olduğundan tüm ölçeğin kapsam geçerliği istatistiksel olarak anlamlı olduğu saptandi.

Yap1 geçerliğinin değerlendirilmesinde sık kullanılan yöntemlerden biri olan faktör analizi, ölçeğin maddelerin farklı boyutlar altında toplanıp toplanmayacağını incelemek amacıyla yapılmaktadır. ${ }^{17} \mathrm{Bu}$ çalışmada; ölçeğin yapı geçerliği bölümünde AFA ve DFA yapıldı. Öncelikli olarak ölçeğin örneklem büyüklüğünün yeterli olup olmadığını gösteren KMO testi ve ölçeğin faktör analizi için uygun olup olmadığını belirleyen Bartlett Testi uygulandı. KMO değerine bakılarak örneklem büyüklüğünün yeterliliği değerlendirilmektedir. KMO değeri 0,90-1,00 arasında ise mükemmel, 0,80-0,89 arasında olduğunda çok iyi, 0,70-0,79 arasında olduğunda iyi, 0,600,69 arasında olduğunda orta, 0,50-0,59 arasında olması örneklem büyüklüğünün zayıf olduğunu göstermektedir. Değerin 0,50'nin altında olması örneklem büyüklüğünün kabul edilemez olduğunu belirtmektedir. ${ }^{11,18} \mathrm{Bu}$ çalışmada KMO değerinin 0,826 bulunması örneklem büyüklüğünün yeterlilik bak1mından "çok iyi" düzeyde olduğunu göstermektedir. Ayrıca örneklemin faktör analizi için uygunluğunu değerlendirmek amacıyla yapılan Bartlett Küresellik Testi sonucunun istatistiksel açıdan anlamlı olması gerekmektedir. ${ }^{11,18}$ Çalışmada Bartlett Küresellik Testi analizi sonucu $\mathrm{X}^{2}=1005, p=0,000$ şeklinde olup anlamlı bulunmuştur. Bu sonuçlar örneklem büyüklüğünün faktör analizi için uygun olduğunu göstermektedir.

Literatürde AFA oluşturulan faktör yüklerinin toplam varyansı açıklama oranı \%40-\%60 arasında olmasının yeterli kabul edileceği bildirilmiştir. ${ }^{11} \mathrm{Bu}$ 
çalışmada "EG:EP Ölçeği”" taslağının AFA analiz sonuçları incelendiğinde; "Profesyonek destek" alt boyutu toplam varyansın \%19,058'ini, "Endişe ve İzolasyon" alt boyutu \%21,047'sini ve "Güven” alt boyutu ise toplam varyansın \%16,221'ini açıklamaktadır. Ölçeğin tüm alt boyutlar ile birlikte toplam varyansın \%56,874 'ünü açıkladığı bulunmuştur. Boykova'nın çalışmasında toplam varyansın \%54,67 olduğu gösterilmiş olup çalışma sonucumuz ile benzer özelliktedir. ${ }^{8}$

Hangi maddelerin hangi faktörlere yüklendiğini belirlemek için yapılan faktör analizinde; "Endişe" ve "izolayon" alt boyutlarına ait maddelerin tek faktör altında toplanmasından dolayı bu iki alt boyut birleştirilerek tek boyut adı altında "endişe ve izolasyon" şeklinde yer almıştır. Ölçek sahibi ile görüşerek üç alt boyut ile çalışmaya devam edilmiştir. Bu durum, kültürel farklılıklar, kullanılan psikolojik terimlerin yanlış karşılığı, ebeveynlerin izolasyon alt boyutuna ait ifadeleri de endişe yaşıyor gibi algılamasından dolayı söylenebilir. ${ }^{19,20} \mathrm{Bu}$ nedenle farklı kültürlerden ölçek uyarlama çalışmalarında geçerlik ve güvenirlik değerlerinin farklı olması olağandır.

AFA'den sonra, doğrulayıcı faktör analizi için çıkan yapının test edilmesi amaçlanmıştır. Doğrulayıcı faktör analizi, bir faktörü oluşturan maddelerin faktörle ilişkisinin yeterli olup olmadığını değerlendirmektedir. ${ }^{11} \mathrm{Bu}$ analiz ile birlikte, ölçek ve alt boyutlarının yeniden değerlendirmesi yapılmaktadır. AFA sonrası mutlaka yapılması önerilmektedir. ${ }^{21}$ Ölçek modelinin doğrulanması için LISREL, EQS ve AMOS gibi çeşitli paket programlar kullanılmaktadır. $^{22} \mathrm{Bu}$ çalışma AMOS 22.0 paket programı ile değerlendirilmiştir. Doğrulayıcı faktör analizi ile elde edilen faktörler ile değişkenler arasında yeterli düzeyde ilişki olup olmadığı, faktörlerin birbirinden bağımsız olup olmadığı, belirlenen faktörlerin orijinal yapıyı açıklamakta yeterli olup olmadığı, değişkenler ile faktörler arasında doğru ilişki kurulup kurulmadığ 1 test edilir. ${ }^{23}$ On yedi maddeden oluşan yapıyı doğrulamak için kurulan ölçüm modeli analiz edilmiştir. Modelin AFA 17 madde 3 alt boyut ile doğruladığı görülmüştür. Yapılan DFA'da ölçekteki tüm maddelerin faktör yüklerinin 0,35- 0,91 arasında olduğu görülmüştür (Tablo 3). Yapıyı açıklamak için genellikle faktör yük değeri 0,30'un altında olan maddelerin analizden çıkartılması gerektiği belirtilmiştir. ${ }^{11,15,24}$ Ölçek maddelerinin faktör yüklerinin belirtilen referans değerin üzerinde olması yapı geçerliğinin sağlandığını göstermiştir.

Ölçeğin orijinalindeki yapının Türk ebeveynlerde doğrulanıp doğrulanmadığını belirlemek için DFA sonucu uyum indeksi değerlerinden $\chi^{2} / \mathrm{sd}<3$, $\mathrm{CFI} \geq 0,95$ değerleri alanyazında belirtilen ölçütlere göre, mükemmel uyumu gösterirken; RMSEA $\leq$ $0,08, \mathrm{GFI} \geq 0,85, \mathrm{TLI} \geq 0,90, \mathrm{AGFI} \geq 0,85$ değerleri de kabul edilebilir düzeydedir. ${ }^{11,15,24,25}$

Ölçeğin güvenirliğinin hesaplanmasında Cronbach's alfa güvenirlik katsayısı, madde ayırt edicilik testi ve test tekrar test yöntemi kullanılmıştır. Ölçme aracının güvenirlik katsayısının olabildiğince 1'e yakın olması istenmektedir. Alfa katsayısına bağlı olarak ölçeğin güvenirliği; 0,40 'dan küçük ise ölçme aracı güvenilir değil, 0,40-0,59 arası ise ölçeğin güvenirliği düşük, 0,60-0,79 arası ise ölçek oldukça güvenilir, 0,80-1,00 arası ise ölçek yüksek derecede güvenilir şeklinde değerlendirmektedir. ${ }^{11}$ Literatürde yer alan çalışmalarda ölçeğin güvenirliğinin tespitinde en çok Cronbach Alpha katsayısı kullanılmakta olup, bu sayının 0,6 değerinden daha büyük değerlerin dikkate alınması önerilmektedir. ${ }^{26}$ Yapılan bu çalışmada endişe ve izolasyon, Profesyonel destek ve güven alt boyutu Cronbach alfa değerleri sirasıyla 0,835; 0,837 ve 0,795 olarak bulunmuş olup tüm ölçek için bu değer 0,850 olarak gösterilmiştir. Boykova çalışmasında Cronbach alfa değerleri 0,77-0,86 arasında değişmekte olup Japonca versiyonda ise 0,89 olduğu bildirilmektedir. ${ }^{8}{ }^{14}$ Diğer çalışmalarla karşılaştırıldığında bu çalışmanın sonuçları benzer olup, ölçeğin yüksek derecede güvenilir olduğunu göstermektedir. En sık kullanılan güvenirlik yöntemlerinden bir digeri ise test tekrar test analizidir. Test tekrar test analizi ile ölçeğin tekrarlayan uygulamalarda tutarlı olması ve zamana göre değişmezliği incelenmektedir. ${ }^{17}$ Test-tekrar test yönteminde ölçeğin aynı bireylere, aynı koşullarda ve önemli derecede hatırlamalar1 önleyecek kadar uzun, fakat ölçülecek özellikte önemli değişmeler olmasına izin vermeyecek kadar kısa bir zaman aralığında iki kez uygulanması önerilmektedir. ${ }^{11}$ Her iki uygulamadan alınan puan ortalamalarının karşılaştırılarak iki ölçüm arasında istatistiksel açıdan anlamlı farkın olmaması, sonuçların zamana karşı değişmeyerek benzer ve güvenilir olduğunu göstermektedir. Bu amaçla iki ölçüm arasındaki zaman aralığı genellikle iki-üç ve dört-altı hafta arasında olmalıdır. ${ }^{27} \mathrm{Bu}$ çalışmada ise ölçek literatüre uygun olarak iki hafta arayla 36 kişiye uygulanmıştır. Uygulanan tekrar test ile ilk test arasında yüksek uyum olduğu görülmektedir ( $\mathrm{ICC}=0,712$ ).

Sonuç olarak ölçeğin dil kapsam geçerliği, yapı geçerliği, ayırt edici geçerlik ve güvenirlik değerlerine dayanarak Eve Geçiş: Preterm Ebeveyn Ölçeği'nin 
preterm bebeğe sahip ebeveynlerin eve geçişteki sorunlarının belirlenmesini ölçme ve değerlendirmede geçerli ve güvenilir bir ölçme aracıdır.

Etik Komite Onayı: Sakarya Üniversitesi Tıp Fakültesi Girişimsel Olmayan Etik Kurul onayı alınmıştır (Tarih: 03/07/2019, karar no: 39).

Çıkar Çatışması: Yazarlar çıkar çatışması bildirmemektedir.

Yazar Katkıları: Fikir/Kavram-HZ, NÇ; TasarımHZ, NÇ, ÖT; Denetleme/Danışmanlık-HZ, NÇ; Veri Toplama ve İşleme-ÖT, HZ; Analiz ve Yorum-HZ; Kaynak Taraması-HZ, ÖT; Makalenin Yazımı-HZ, ÖT; Eleştirel Düşünme-HZ, NÇ, ÖT; Araştırmanın Bütçesi-HZ, ÖT.

Hakem değerlendirmesi: Dış bağımsız.

Teşekkür: Araştırmaya katılan tüm ebeveynlere, çalışmanın istatistik analizine katkı sağlayan Prof. Dr. Mustafa Cahit ÜNĞAN'a ve Reyhan KAPLAN'a teşekkür ederiz.

\section{KAYNAKLAR}

1. Albayrak S, Büyükgönenç AL. Yenidoğan yoğun bakım ünitesinde ebeveyn memnuniyet ölçeği'nin Türkçeye uyarlanması: Güvenirlik ve geçerlik çalışması. Koç Üniversitesi Hemşirelikte Eğitim ve Araştırma Dergisi. 2019;16(4):313323.

2. Aydon L, Hauck Y, Murdoch J, Siu D, Sharp M. Transition from hospital to home: Parents perception of their preparation and readiness for discharge with their preterm infant. J Clin Nurs. 2018;27(1-2):269-277.

3. Galeano SPO, Marín SCO, Semenic S. Preparing for post-discharge care of premature infants: Experiences of parents. Invest. Educ. Enferm. 2017;35(1):100-108.

4. McGowan EC, Du N, Hawes K, Tucker R, O'Donnell M, Vohr B. Maternal mental health and neonatal intensive care unit discharge readiness in mothers of preterm infants. J Pediatr. 2017;184:68-74.

5. Batman D, Şeker S. Web tabanlı eğitimin prematüre yenidoğanların ebeveynlerinin bakımdaki özgüven ve kayg1 düzeylerine etkisi. DEUHFED. 2019;12(2):107-115.

6. Arslan FT, Turgut R. Prematüre bebeklerin evdeki bakım gereksinimleri ve bakım verme yeterliliklerini algılama durumları. DEUHFED. 2013;6(3):119-124.
7. Galeano MD, Carvajal BV. Coping in mothers of premature newborns after hospital discharge. Newborn and Infant Nursing Reviews. 2016;16 (3):105-109.

8. Boykova M. Transition from hospital to home in parents of preterm infants: Revision, modification, and psychometric testing of the questionnaire. J Nurs Meas. 2018;26(2):296-310.

9. Adama EA, Bayes S, Sundin D. Parents' experiences of caring for preterm infants after discharge from Neonatal Intensive Care Unit: A meta-synthesis of the literatüre. Journal of Neonatal Nursing. 2016;22(1):27-51.

10. Noergaard B, Ammentorp J, Fenger-Gron J, Kofoed PE, Johannessen H. Fathers' needs and masculinity dilemmas in a neonatal intensive care unit in Denmark. Advances in Neonatal Care. 2017;17(4):E13-E22. doi: 10.1097/ ANC.0000000000000395

11. Alpar R. Spor, sağlık ve eğitim bilimlerinden örneklerle uygulamalı istatistik ve geçerlikgüvenirlik-SPSS'de çözümleme adımları ile birlikte. 3. Baskı. Ankara: Detay Yayıncılık; 2014.

12. Kenner C, Flandermeyer A, Spangler L, Thornburg P, Spiering D, Kotagal U. Transition from hospital to home for mothers and babies. Neonatal Netw. 1993;12(3):73-77.

13. Boykova M, Kenner C. Transition from hospital to home for parents of preterm infants. The Journal of Perinatal \& Neonatal Nursing. 2012;26 (1):81-87.

14. Uehara K, Maeda K. Transition-to-home: premature parent scale Japanese version of the transition-to-home: premature development of parent scale) -Examination of surface validity by preliminary survey. Bulletin of Okinawa Prefectural College of Nursing. 2018;19:19-24.

15. Seçer İ. Psikolojik test ve geliştirme ve uyarlama süreci. SPSS ve Lisrel uygulamaları. 2. Bask1. Ankara: Anı Yayıncılık; 2018.

16. Yeşilyurt S, Çapraz C. Ölçek geliştirme çalışmalarında kullanılan kapsam geçerliği için bir yol haritas1. Erzincan Üniversitesi Eğitim Fakültesi Dergisi. 2018;20(1):251-264.

17. Karakoç FY, Dönmez Y. Ölçek geliştirme çalışmalarında temel ilkeler. Tıp Eğitimi Dünyası. 2014;13(40):39-49. 
18. Kalaycı Ş. SPSS uygulamalı çok değişkenli istatistik teknikleri. Ankara: Dinamik Akademi Yayınları; 2018.

19. Korkmaz M. Psikolojik ölçmenin yeni kuralları ve Türkiye'deki durumu. Türk Psikoloji Bülteni. 2007;13(40):8-14.

20. Erkuş A. Psikometrik terimlerin Türkçe karşılıklarının anlamları ile yapılan işlemlerin uyuşmazlığı. Eğitimde ve Psikolojide Ölçme ve Değerlendirme Dergisi. 2010;1(2):72-77.

21. Boetang GO, Neilands TB, Frongillo EA, Melgar -Quinonez HR, Young SL. Best practices for developing and validating scales for health, social and behavioral research: A Primer. Front. Public Health. 2018;6:1-18.

22. Çokluk Ö, Sekercioğlu G, Büyüköztürk S. Sosyal bilimler için çok değişkenli istatistik: SPSS ve LISREL uygulamaları. 3. Bask1. Ankara: Pegem Akademi; 2014.

23. Meydan $\mathrm{CH}$, Şeşen H. Yapısal eşitlik modellemesi AMOS uygulamaları. 2. Bask1. Ankara: Detay Yayıncılık; 2015

24. Karagöz Y. SPSS-AMOS-META uygulamalı istatistiksel analizler. Ankara: Nobel Yayıncılık; 2019.

25. Erkorkmaz Ü, Etikan İ, Demir O, Özdamar K, Sanisoğlu SY. Doğrulayıcı faktör analizi ve uyum indeksleri. Turkiye Klinikleri Journal of Medical Sciences. 2013;33(1):210-223.

26. Pai YP, Chary ST. Dimensions of hospital service quality: a critical review perspective of patients from global studies. Int J Health Care Qual Assur. 2013;26 (4):308-340.

27. Esin MN. Hemşirelikte araştırma. Veri toplama yöntem ve araçları, veri toplama araçlarının güvenirlik ve geçerliliği. I. Baskı. İstanbul: Nobel Tıp Kitapevi; 2014. 
Tablo 1. Eve geçiş: Preterm ebeveyn ölçeği’nin Kaiser Meyer Olkin değeri (KMO) ve Bartlett küresellik.

\begin{tabular}{|l|l|l|}
\hline \multicolumn{2}{|l|}{ Kaiser Meyer Olkin (KMO) } & $\mathbf{0 , 8 2 6}$ \\
\hline \multirow{2}{*}{ Bartlett Küresellik Testi } & $\mathrm{X}^{2}$ & 1005 \\
\cline { 2 - 3 } & $\mathrm{sd}$ & 136 \\
\cline { 2 - 3 } & $\mathrm{p}$ & $<\mathbf{0 , 0 0 1 *}$ \\
\hline
\end{tabular}

*: Anlamlılık düzeyi $\mathrm{p}<0,001$. 
Tablo 2. Eve geçiş: Preterm ebeveyn ölçeği'nin faktör analizi, varyans yüzdeleri ve güvenirlik analizi sonuçları.

\begin{tabular}{|c|c|c|c|c|}
\hline Değişkenler & $\begin{array}{l}\text { Faktör } \\
\text { Yükleri }\end{array}$ & $\begin{array}{l}\text { Ortala- } \\
\mathbf{m a} \pm \text { SD }\end{array}$ & $\begin{array}{l}\text { Açıklanan } \\
\text { Varyans } \\
\text { Yüzdeleri* }\end{array}$ & $\begin{array}{l}\text { Cronbach's } \\
\text { Alpha De- } \\
\text { ğerleri** }\end{array}$ \\
\hline Faktör 1 (Profesyonek destek) & & & 19,058 & 0,837 \\
\hline $\begin{array}{l}\text { 5-Bebeğime bakan sağlık çalışanı sorularıma } \\
\text { cevap vermek için zaman ayırıyor. }\end{array}$ & 0,765 & $3,83 \pm 1,47$ & & \\
\hline $\begin{array}{l}\text { 7-Bebeğime bakan sağlık çalışanının tavsiyelerine } \\
\text { güveniyorum. }\end{array}$ & 0,684 & $4,29 \pm 1,07$ & & \\
\hline $\begin{array}{l}\text { 12-Bebeğimle ilgilenen sağlık çalışanları, beni } \\
\text { dinlemek için bana zaman ayırıyor. }\end{array}$ & 0,877 & $4,00 \pm 1,28$ & & \\
\hline $\begin{array}{l}\text { 14-Sağlık çalışanları, beni ve bebeğimi destekli- } \\
\text { yor. }\end{array}$ & 0,816 & $4,21 \pm 1,07$ & & \\
\hline $\begin{array}{l}\text { 16-Bebeğim hakkında sorularım olduğunda sora- } \\
\text { bileceğim sağlık çalıșanları var. }\end{array}$ & 0,686 & $3,77 \pm 1,47$ & & \\
\hline Faktör 2 (Endişe ve İzolasyon ) & & & 21,595 & 0,835 \\
\hline $\begin{array}{l}\text { 3-Sürekli olarak bebeğimin hastalanabileceğinden } \\
\text { korkuyorum. }\end{array}$ & 0,674 & $2,40 \pm 1,44$ & & \\
\hline $\begin{array}{l}\text { 4-Bebeğim hakkındaki hislerimi paylaşmakta } \\
\text { zorlanıyorum. }\end{array}$ & 0,656 & $3,79 \pm 1,52$ & & \\
\hline 6-Çoğu zaman kendimi üzgün hissediyorum. & 0,695 & $3,19 \pm 1,55$ & & \\
\hline $\begin{array}{l}\text { 9-Bebeğimin iyi olduğundan emin olmak } \\
\text { (görmek) için sürekli bebeğimi kontrol ediyorum. }\end{array}$ & 0,541 & $1,53 \pm 0,87$ & & \\
\hline $\begin{array}{l}\text { 11-Hiç kimse gerçekten ne hissettiğimi anlamı- } \\
\text { yor. }\end{array}$ & 0,734 & $2,54 \pm 1,55$ & & \\
\hline 13-Kendimi tamamen yalnız hissediyorum. & 0,657 & $3,70 \pm 1,39$ & & \\
\hline $\begin{array}{l}\text { 15-Danışmanlığa ihtiyacım olduğunu hissediyo- } \\
\text { rum. }\end{array}$ & 0,552 & $3,52 \pm 1,52$ & & \\
\hline $\begin{array}{l}\text { 17-Bebeğim ile ilgili endişelendiğim için geceleri } \\
\text { uyumakta zorluk çekiyorum. }\end{array}$ & 0,777 & $3,27 \pm 1,60$ & & \\
\hline Faktör 3 (Güven) & & & 16,221 & 0,795 \\
\hline 1-Bebeğimin bakımında kendime güveniyorum. & 0,869 & $4,62 \pm 0,80$ & & \\
\hline 2-Evde bebeğime bakarken rahat hissediyorum. & 0,872 & $4,51 \pm 0,93$ & & \\
\hline 8-Bebeğime nasıl bakabileceğimi biliyorum. & 0,669 & $4,50 \pm 0,86$ & & \\
\hline 10-Bebeğimi nasıl besleyeceğimi biliyorum. & 0,604 & $4,59 \pm 0,79$ & & \\
\hline
\end{tabular}

* Ölçek toplam varyansı: 56,874; **Ölçek toplam Cronbach's Alpha: 0,850. 
Tablo 3. Ölçüm modelinin uyum indeks değerleri ve iyi uyum değerleri.

\begin{tabular}{|l|c|c|c|}
\hline & Uyum İndeks Değerleri & Mükemmel Uyum Değerleri & $\begin{array}{c}\text { Kabul Edilebilir } \\
\text { Uyum Değerleri }\end{array}$ \\
\hline$\chi^{\mathbf{2} / \mathbf{s d}}$ & 1,405 & $\leq 3$ & $\leq 5$ \\
\hline GFI & 0,889 & 0,90 ve üzeri & $\geq 0,85$ \\
\hline CFI & 0,950 & 0,95 ve üzeri & $\geq 0,85$ \\
\hline TLI & 0,940 & 0,95 ve üzeri & $\geq 0,85$ \\
\hline AGFI & 0,851 & 0,90 ve üzeri & $\geq 0,85$ \\
\hline RMSE & 0,053 & $\leq 0,05$ & $\leq 0,08$ \\
A & & & \\
\hline
\end{tabular}

GFI: Goodness of fit index; CFI: Comparative fit index; TLI:Tucker-Lewis index; AGFI: Adjusted goodness of fit index; RMSEA:Root Mean Square Error of approximation. 
Tablo 4. Eve Geçiş: Preterm Ebeveyn Ölçeği ve alt boyutları için test-tekrar test sonuçları.

\begin{tabular}{|l|c|c|c|}
\hline & ICC * & $\begin{array}{c}\text { \%95 Güven Aralığında ICC } \\
\text { Değerleri }\end{array}$ & p \\
\hline Endişe ve İzolasyon & 0,585 & $(0,358-0,756)$ & \multirow{2}{*}{$<0,001$} \\
\hline Profesyonel destek & 0,719 & $(0,545-0,841)$ & \\
\hline Güven & 0,635 & $(0,391-0,797)$ & \\
\hline Ölçek Toplam & 0,712 & $(0,562-0,829)$ & \\
\hline
\end{tabular}

*ICC: Sınıf içi korelasyon. 


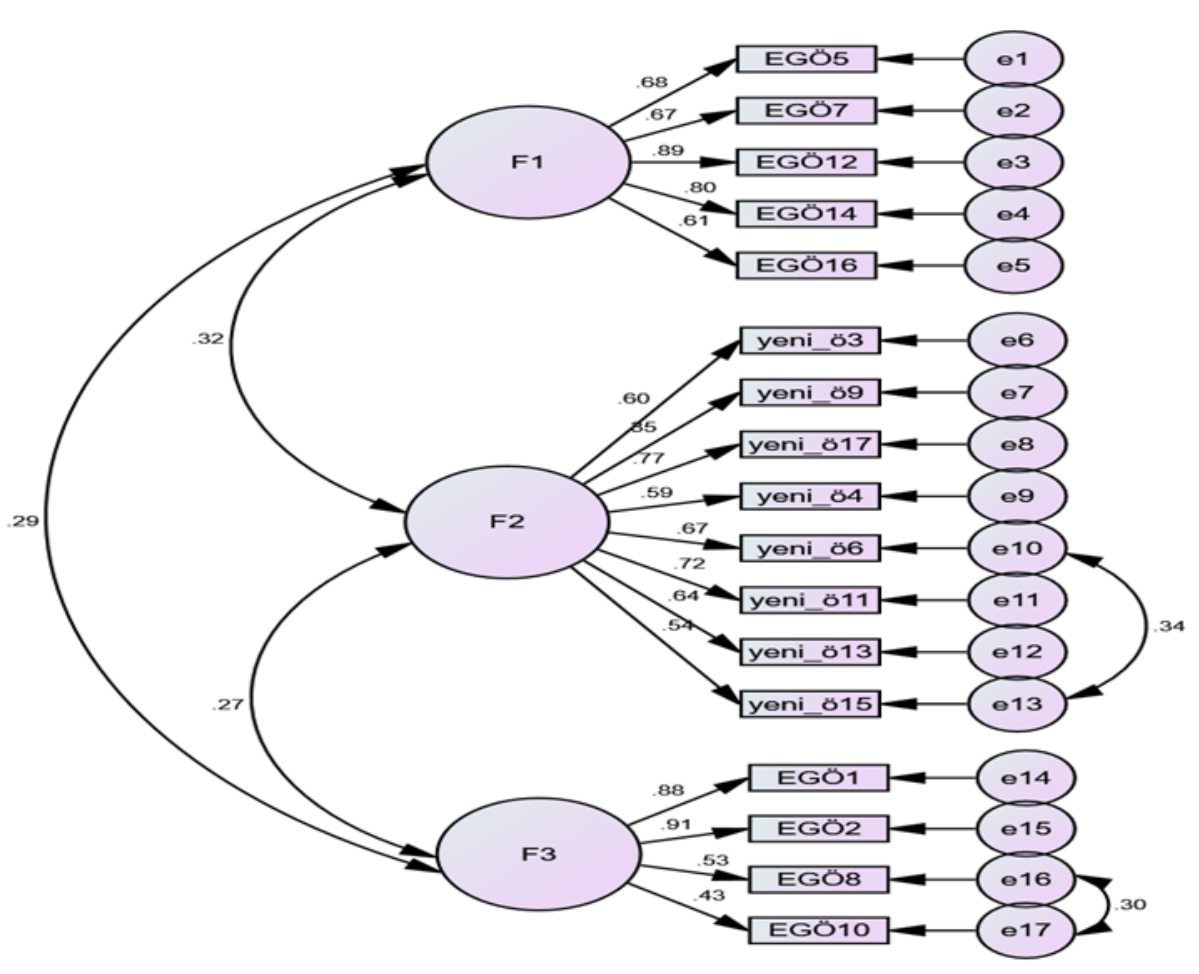

Şekil 1. Eve geçiş: Preterm Ebeveyn Ölçeği'nin ölçüm modeli. 